\title{
Formation of the future teacher's readiness to work with gifted children
}

\author{
A.S. Seredkina, E.L. Fedotova, E.A. Nikitina*, A.V. Kazorina, and A.A. Shirina \\ Irkutsk State University, Karla Marxa Str. 1, 664003 Irkutsk, Russia
}

\begin{abstract}
The modern realities reflect the development trend of the leading education mainstream in the Russian Federation, the priority area of the state strategy - the formation of optimal conditions for effective education of a fundamentally new generation, prepared for active independent activity in developing scientific, strategic, and economic potential and increasing the status of a sovereign state both in the foreign and domestic policy of the country. Given the social needs of the population, the state order modernizes and forms new tasks, the paramount of which is the need to organize the educational process aimed at the successful formation and development of a citizen of Russian society, fully committed to finding and learning new things. A modern representative of a new society, undoubtedly, must have developed creative abilities, demonstrate pronounced talent in one or several spheres of activity, independently make important decisions, and realize the scope of responsibility and the need to choose consciously a path of personal development.
\end{abstract}

\section{Introduction}

The modern educational space is focused on helping in the formation of the young generation qualified for a rapidly changing world. The qualities of a successful person that ensure his competitiveness are, first of all, professional and academic mobility, and the ability to solve non-routine tasks. These traits constitute general giftedness. As the research of many scientists evidence, only that teacher can work with a gifted child who is ready to interact with them. The demand for readiness to work with gifted children is set out in the documents regulating the activities of teaching staff. Article 77 of the Federal Law "On Education in the Russian Federation" [] provides the guidelines for the need to create pedagogical conditions for working with gifted children, their development in various educational areas, thereby providing a fundamentally new, creative approach to solving their tasks assigned in a certain field of activity. The professional standard of a teacher, approved by Order of the Ministry of Labor and Social Protection of the Russian Federation of 18.10.2013 No. 544 "On the Approval of the Professional Standard of a Reacher" (pedagogical activity in preschool, primary, general, basic general, and secondary general education) [], regulates the provision on the teacher's obligation to master the basics of developmental, pedagogical, correctional psychology, be able to help children in a problem situation or critical conditions and to protect the interests of students and identify and develop their talents. A student of a pedagogical

\footnotetext{
${ }^{*}$ Corresponding author: helen168@yandex.ru
} 
university is not always ready to solve the assigned tasks, thus, we consider it necessary to create special pedagogical conditions for the development of the future teacher's readiness to work with gifted children. Speaking about the implementation of pedagogical conditions that ensure the formation of this readiness, we should dwell on the phenomenon of readiness to work with gifted children and note its special significance in the professional activity of a future specialist who feels the need for self-education, self-development, and selfactualization. To assess the activities of the future teacher, the explicit and implicit theories of creativity and innovation should be considered. This is because this approach determines the teacher's understanding of the goals and objectives of working with gifted children, direct them in their professional activities [1].

The ability of future teachers for creative thinking, which is directly related to the cognitive abilities of graduates of pedagogical universities that provide high cognitive activity among gifted students, deserves special attention [2].

Graduates of pedagogical universities should both have theoretical knowledge about the organization of work with gifted children and understand its specifics: gifted children, as empirical studies show, are more difficult to adapt to the rules and requirements of school education, build relationships with peers. At the same time, they are highly motivated and curious. Working with such children requires a teacher to be creative and skilled.

Analysis of ideas, main approaches, and elements of theoretical prerequisites for the formation of the future teacher's readiness to work with gifted children has shown that the transformation of modern socio-economic conditions makes it increasingly important to develop effective pedagogical conditions, as their implementation will ensure the formation of the future teacher's readiness for effective work with gifted children.

The relevance of the research is determined by the lack of disclosure and substantiation of the problem being studied, the need to further search for ways and create effective pedagogical conditions that ensure the formation of the future teacher's readiness to work with gifted children.

The study of the stated problem found that the domestic psychological and pedagogical theory and practice have accumulated huge experience in organizing interaction with gifted children, and improved and developed approaches to their upbringing and teaching. Based on the results of the analysis of these ideas, as well as the main theoretical prerequisites that contribute to the formation of this type of readiness, we have determined the essence and features of pedagogical interaction with gifted children and outlined priority areas of joint activities and communication of the future teacher with this category of students.

The formation of the future teacher's readiness to work with gifted children is a multifactorial process of building their trajectory of predictable professional activity, professional competence based on the results of high-quality professional training, followed by effective interaction with gifted children.

The readiness of a future teacher to work with gifted children is an integrated professional and personal profile of a future teacher, which includes qualitative cognitive-activity, operational, axiological, motivational, and personal components that demonstrate the readiness of a student of a pedagogical university for professional work with gifted children. Accordingly, this type of readiness presupposes high motivation for creative pedagogical activity, associated with the creation of new ideas, the use of non-standard approaches to solving the problems of children's giftedness, the development of effective methods for identifying and developing children with a particular talent.

In our theoretical research, we have identified the key categories of research, the essence, criteria, and indicators of the readiness of the future teacher to work with gifted children. The experimental part of the work linked psychological and pedagogical theory and practice through the analysis of the level of students' readiness to work with gifted children. The experimental part of the research was to determine and implement pedagogical conditions 
that ensure the effectiveness of training future teachers for interaction with gifted children; conduct pedagogical diagnostics to determine the initial level of students' readiness to interact with this category of children; develop a criterion-diagnostic apparatus to assess the level of readiness of future teachers to interact with gifted children.

The purpose of the experimental work was to identify, with the help of control means and methods, dynamic (static) changes in the correlation between the level of initial readiness of students to work with gifted children at the first stage of the experiment, and the level of the formed readiness through the creation of certain pedagogical conditions at the final stage, and introduce and test in practice these pedagogical conditions that ensure the effective formation of the readiness of future teachers to interact with gifted children.

Following the objective of the research, the experimental tasks were as follows:

1. Determine the initial level of readiness of future teachers to work with gifted children.

2. Structure the algorithm of pedagogical conditions that ensure the formation of students' readiness to work with gifted children.

3. Determine the final level of readiness of future teachers to work with gifted children at the final stage of the experiment.

4. Compare and evaluate the effectiveness of the developed and experimentally tested pedagogical conditions that ensure the formation of the readiness of future teachers to work with gifted students.

The methodological basis of the research was scientific studies by A.M. Matiushkin, A.I. Savenkov, V.S. Iurkevich $[3,4,5]$ on the characteristics of the professional activity of a teacher working with gifted children, and psychological and pedagogical ideas and conceptual provisions interpreting the concept of "giftedness" by D.B. Bogoiavlenskaia, L.I. Larionova $[6,7,8]$.

\section{Materials and Methods}

Based on our review of research literature we have considered the phenomenon of students' readiness to work with gifted children as an integrative quality of a future teacher, characterized by:

- $\quad$ perceptual readiness and highly motivated desire to work with gifted children both in cooperation with other subjects of the educational process (teachers, other students) and independently and unassisted;

- $\quad$ strong emotional involvement in pedagogical work with gifted children;

- $\quad$ strong empathy, sensitivity, and attentiveness to the psychological, physiological, as well as spatial needs of gifted children;

- knowledge and ability to competently operate pedagogical methods of communicative interaction with gifted children;

- self-authentication and search for solutions to problems accompanying the educational process of gifted children;

- a special individual, exceptional and original way of thinking;

- strong self-actualization, self-organization, self-esteem, self-control with subsequent reflection on the organized process of interaction with gifted children;

- a propensity for continuous education, self-development, and self-improvement.

To identify the ways and means of forming the readiness of future teachers to work with gifted children, we have conducted pedagogical diagnostics of the initial level of students' readiness for this type of work, which made it possible to outline a goal with an outlook for the ascertaining stage of the experiment. Following this goal, the tasks were as follows: 
1. Develop a system of criteria for and indicators of the formation of future teachers' readiness to work with gifted children.

2. Select diagnostic tools to determine the level of initial readiness of students of a pedagogical university to work with gifted children.

3. Implement pedagogical diagnostics to determine the initial readiness using the selected methods in a separate group of students of a pedagogical university.

4. Analyze and process the obtained statistics and the results of the pedagogical diagnostics.

The criterion-diagnostic base was in accordance with the structure and levels of development of pedagogical readiness to work with gifted children (Table 1). At the ascertaining stage of our experiment, we used the following methods of pedagogical diagnostics (Table 2).

Table 3 presents the implemented measures of observation, testing, as well as statistics of the questionnaire that have shown generalized initial data on the observed groups of students of the pedagogical university.

Table 1. The criterion-diagnostic base of the readiness of future teachers to work with gifted children

\begin{tabular}{|c|l|l|}
\hline No. & \multicolumn{1}{|c|}{$\begin{array}{c}\text { Structural } \\
\text { readiness } \\
\text { component }\end{array}$} & \multicolumn{1}{c|}{ Description } \\
\hline 1 & $\begin{array}{c}\text { Cognitive-active } \\
\text { the extent of high-quality theoretical knowledge of the phenomenon of giftedness, } \\
\text { signs, characteristics, forms, and methods of organizing the educational process } \\
\text { of gifted children, as well as possession of diagnostic methods, pedagogical } \\
\text { technologies for the development of giftedness, psychological and pedagogical } \\
\text { support of interaction with this category of students }\end{array}$ \\
\hline 2 & Operational & $\begin{array}{l}\text { a system of professional knowledge and skills (communicative, gnostic, } \\
\text { constructive, design and organizational, reflexive), serving as the fundamental } \\
\text { basis for the future professional activity of a student of a pedagogical university, } \\
\text { affecting the effectiveness of the implementation of knowledge in practice }\end{array}$ \\
\hline 3 & $\begin{array}{l}\text { Axiological } \\
\text { component }\end{array}$ & $\begin{array}{l}\text { cognition of the nature of pedagogical values, their place in the real structure of } \\
\text { the integrity of the world, accompanied by a clear ideological pedagogical } \\
\text { orientation with a high level of spiritual and moral qualities; understanding the } \\
\text { importance of identification and the subsequent ontogenesis of a gifted person at } \\
\text { the stage of development of modern education }\end{array}$ \\
\hline 4 & $\begin{array}{l}\text { Motivational } \\
\text { component }\end{array}$ & $\begin{array}{l}\text { characterized by the power of motivation for independent and continuous } \\
\text { cognitive activity, readiness for volitional efforts on the way of implementing } \\
\text { effective interaction with gifted children }\end{array}$ \\
\hline 5 & $\begin{array}{l}\text { Personal } \\
\text { component }\end{array}$ & $\begin{array}{l}\text { the ability and desire for continuous education (self-education), self-knowledge, } \\
\text { self-analysis of professional activity distinct in a high level of development of } \\
\text { social intelligence, functional literacy, an active view of life, emotional positive } \\
\text { stability, reflection }\end{array}$ \\
\hline
\end{tabular}

Table 2. Methods of pedagogical diagnostics of the readiness of future teachers to work with gifted children

\begin{tabular}{|c|l|l|}
\hline No. & \multicolumn{1}{|c|}{ Method } & \multicolumn{1}{c|}{ Content } \\
\hline 1 & $\begin{array}{l}\text { Questionnaire } \\
\text { survey }\end{array}$ & $\begin{array}{l}\text { The developed questionnaire considers the outlined goals and objectives of our study, } \\
\text { which made it possible to assess the level of formation of the readiness of future } \\
\text { teachers to work with gifted children, to determine the degree and nature of motivation } \\
\text { of students of a pedagogical university, to assess the ability to reflect on knowledge } \\
\text { and opportunities, to identify difficulties arising for students in organizing the } \\
\text { educational process with gifted children }\end{array}$ \\
\hline 2 & Testing & $\begin{array}{l}\text { The use of adapted questions from the previously developed "Test to determine the } \\
\text { teacher's inclination to work with gifted children" A. E. Bogoiavlenskaia, A.V. } \\
\text { Brushlinskii }\end{array}$ \\
\hline
\end{tabular}


Table 2. Continued

\begin{tabular}{|c|l|l|}
\hline 3 & Conversation & $\begin{array}{l}\text { Conversation in a relatively informal pedagogical environment identified several } \\
\text { indicators that are indirectly or directly related to the axiological and motivational } \\
\text { components of the readiness of future teachers to work with gifted children; the } \\
\text { attitude of students of a pedagogical university to giftedness as a phenomenon of } \\
\text { modern education, as well as to the need to identify and support it; professional vector, } \\
\text { expressed in interest and desire to interact with gifted children in pedagogical } \\
\text { activities }\end{array}$ \\
\hline 4 & Observation & $\begin{array}{l}\text { A set of observation activities, accumulating a multidimensional assessment of the } \\
\text { level of formation of the readiness of future teachers to work with gifted children; as } \\
\text { a result, we assessed the degree of independence and creativity of judgments in the } \\
\text { course of an oriented problem dialogue; the degree of theoretical knowledge in } \\
\text { children's giftedness; the level of formation of general subject (information and } \\
\text { logical) skills; the level of erudition and flexibility of thinking; personal characteristics } \\
\text { of students associated with the ability for dialogue (student-teacher, student-student) } \\
\text { during the educational process within the curriculum. The questions of the observation } \\
\text { program had a single statistical form, which also reflected the results of the previous } \\
\text { questioning, testing, and conversation. }\end{array}$ \\
\hline
\end{tabular}

Having identified the dominant research trends, the nature of the manifestation of quantitative indicators, we divided the students participating in the experiment into three groups, reflecting the potential readiness to interact with gifted students (Table 4).

The conducted pedagogical diagnostics has demonstrated in percentage terms the indicators of the initial readiness of students to work with gifted children of the studied sample, graphically expressed in the diagram (Fig. 1), as well as the degree of the student's initial propensity to work with gifted children (Fig. 2).

Table 3. Summary of the initial diagnostics of the readiness of future teachers to work with gifted children

\begin{tabular}{|c|c|c|c|}
\hline No. & Indicators & $\begin{array}{l}\text { Quantitative } \\
\text { indicators }(\mathrm{n}= \\
45 \text { people })\end{array}$ & In $\%$ \\
\hline 1 & $\begin{array}{l}\text { Convinced of the need to improve modern } \\
\text { forms and methods of pedagogical work with } \\
\text { gifted children }\end{array}$ & 35 & 77 \\
\hline 2 & $\begin{array}{l}\text { Admit the likelihood of effectively working } \\
\text { with gifted children in the course of } \\
\text { pedagogical activities }\end{array}$ & 25 & 55 \\
\hline 3 & $\begin{array}{l}\text { Do not associate their future professional } \\
\text { activities with the work with gifted children }\end{array}$ & 4 & 8 \\
\hline 4 & Find it difficult to answer & 18 & 40 \\
\hline 5 & $\begin{array}{l}\text { Want to study the peculiarities of identifying } \\
\text { and developing gifted children }\end{array}$ & 14 & 32 \\
\hline \multirow[t]{4}{*}{6} & $\begin{array}{l}\text { Argue to feel sympathetic to the children } \\
\text { showing the following characteristic signs: }\end{array}$ & & \\
\hline & - originality; & 30 & 67 \\
\hline & - confidence; & 13 & 30 \\
\hline & - averaged. & 8 & 17 \\
\hline 7 & $\begin{array}{l}\text { Interested in monitoring their level of } \\
\text { professional competence and readiness to work } \\
\text { with gifted children }\end{array}$ & 27 & 59 \\
\hline 8 & $\begin{array}{l}\text { Strive to increase their methodological and } \\
\text { theoretical knowledge about the phenomenon } \\
\text { of children's giftedness }\end{array}$ & 33 & 73 \\
\hline
\end{tabular}


Table 4. Differentiation of respondents during initial pedagogical diagnostics of the readiness of future teachers to work with gifted children

\begin{tabular}{|c|l|l|}
\hline No. & \multicolumn{1}{|c|}{$\begin{array}{l}\text { Group of } \\
\text { readiness }\end{array}$} & \multicolumn{1}{c|}{ Description } \\
\hline 1 & Apt & $\begin{array}{l}\text { Demonstrate a high enough level of self-organization, personal, creative, and social } \\
\text { intelligence, high desire to interact with gifted children; proactive, active } \\
\text { participation in various types of the creative pedagogical activity, able enough to } \\
\text { predict learning and results, analyze and evaluate existing conditions, determine the } \\
\text { most effective methods of action in various pedagogical situations, outline the most } \\
\text { suitable psychological and pedagogical methods and means of work with gifted } \\
\text { children. }\end{array}$ \\
\hline 2 & Neutral & $\begin{array}{l}\text { Predisposed to interact with gifted children, however, need to increase professional } \\
\text { readiness for this type of interaction, additional motivation, improvement of } \\
\text { volitional qualities, intellectual efforts, master modern methods, knowledge about } \\
\text { the trends and prospects of the development of Russian education, pedagogical } \\
\text { technologies. This set of measures serves as a vector for increasing the effectiveness } \\
\text { of their pedagogical activity. } \\
\text { At the same time, there is a significant lack of external stimulation of creative } \\
\text { activity, which ensures continuous professional development. }\end{array}$ \\
\hline 3 & Not apt & $\begin{array}{l}\text { Low interest in working with gifted children, lack of knowledge of the modern } \\
\text { methodology of scientific cognition and modern pedagogical technologies, inability } \\
\text { to reflexively assess their professional and personal development; emotionally } \\
\text { unstable and tend to refrain from pedagogical practice with gifted children in the } \\
\text { future. } \\
\text { Such students have little interest in creativity, even in the presence of external } \\
\text { incentive factors; have a feeling of dissatisfaction and anxiety in non-standard } \\
\text { situations associated with new pedagogical problems. In pedagogical practice, they } \\
\text { adhere to the previously developed model of behavior, prefer to refrain from taking } \\
\text { risks and being proactive. }\end{array}$ \\
\hline
\end{tabular}

\section{Results and Discussion}

The forming stage of the research involved several activities:

- testing of the model of the future teacher's readiness to work with gifted children, its correction and transformation, a pedagogical experiment during a Moodle-based distance learning course, aimed at introducing a pedagogical model with its subsequent implementation in practice;

- $\quad$ priority areas of activities: methodological and informational support of students of a pedagogical university on the problems of identifying and accompanying children with clear and potential signs of giftedness in the modern education realities.

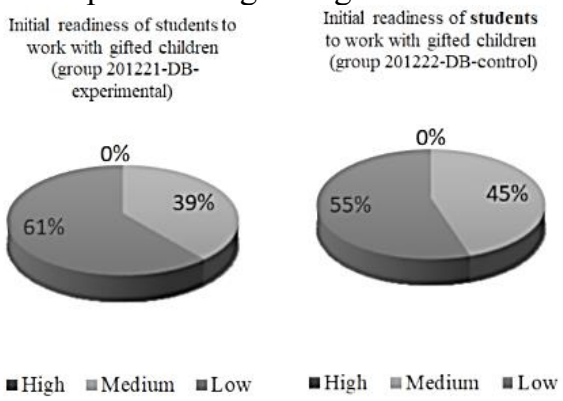

Fig. 1. Initial readiness of future teachers to work with gifted children (\%)

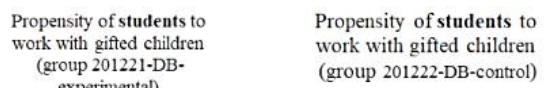

Propensity of students to work with gifted children (group 201222-DB-control)
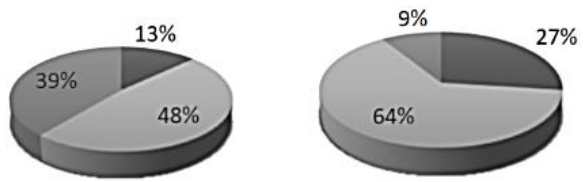

Apt $\quad$ Neutral $\quad$ Not apt
of future teachers

घApt $=$ Neutral $\mathbf{\text { Not apt }}$ to work with gifted children (\%)

The main goal of the second stage of the study was to put into practice pedagogical conditions promoting the effective formation of future students' readiness to work with gifted 
students. At this stage, it was advisable to act in two steps, consistently complementing each other and forming the theoretical readiness of students to interact with gifted children.

The first step of the second stage of the experiment involved the active participation of students of a pedagogical university in building an algorithm for interaction with gifted students, which is based on reconstructive search and cognitive activity, with a conscious reproduction of the obtained theoretical knowledge, modeling of the process of identifying and accompanying students with signs of giftedness, the ability to timely and independently implement a search for solutions to new pedagogical problems in the course of the educational process.

The second step was to create pedagogical conditions for effective work with gifted children.

At the experimental stage, we had to develop and implement a training course and organize the educational process through distance learning technologies based on various methods of delivering electronic content and other available tools for the communication of students and the teaching staff in the electronic information and educational environment (EIEE).

The created pedagogical conditions were implemented within the framework of distance learning on the Moodle platform, through the educational portal of Irkutsk State University; these conditions had the characteristics of search and cognitive activity and were aimed at developing in students of a pedagogical university an intellectual and content component in mastering the phenomenon of children's giftedness.

Based on the results of diagnostic activities at the first stage of the experiment, as well as on the goals of this study, we set the following tasks:

- $\quad$ selection of pedagogical means that enhance the readiness of future teachers to work with gifted children;

- implementation of pedagogical conditions that contribute to the effective formation of students' readiness to work with gifted children;

- development of cognitive motivation among students of a pedagogical university through the formation of a stable cognitive interest in the study of the phenomenon of children's giftedness, the problems of identifying and providing psychological and pedagogical support to gifted children, as well as enhancing the open cognitive position of students;

- development of general subject skills in students, such as goal-setting, search and analysis of information, independent selection of scientific theoretical material, pedagogical planning, the ability to work in micro and macro groups, improvement of communication skills;

- development of reflexive skills of future teachers through their focus on a reflective position, promotion of the need to analyze their professional activities associated with children's giftedness.

This pedagogical study exposed groups of students to one independent variable of different degrees. The students were divided into two groups: experimental and control.

Repeated pedagogical diagnostics and analysis of the products of students' activity helped us to reveal the effectiveness of the experimental formation of the readiness of future teachers to work with gifted children:

- a graphical structuring of the system for identifying and developing gifted children;

- development of an electronic brochure (electronic information booklet) by sections reflecting age-related specificity, signs of children's giftedness, psychological and pedagogical characteristics of gifted children, criteria and types of giftedness, classification of types of children's giftedness;

- building of the structural-logical scheme "Organization of pedagogical activity with gifted children" in compliance with the sequence and priority of the elements; 
- $\quad$ drawing up a case on the topic: "Ways of solving problems in organizing and carrying out work with gifted children" with clearly set didactic goals, with a high level of relevance, considering both the modern aspects and regional specifics, with the subsequent protection of copyright works, in on-online conferences;

- drawing up a "profile" of a modern teacher with high readiness to work with gifted children, with the identification of the five most important professional and/or personal traits.

To succeed in each task and the timely provision of the product of the intellectual activity, students of the pedagogical university were provided in advance and completely with a regulatory framework; theoretical, scientific and practical, and methodological material; relevant links to thematic scientific articles; access to textbooks, monographs, video lectures on the phenomenon of children's giftedness, the rules and procedure for identifying and developing gifted students, on the problems and prospects for the development of the education system for gifted children, etc.

\section{Conclusion}

Systematic monitoring of the intermediate results made it possible to assess the degree of mastering theoretical material, methods of cognitive activity, and the level of formation of a general subject (educational-informational and educational-logical) skills, the ability of future teachers to work independently.

The experimental group consisted of the 2nd-year undergraduate students, specialty: 44.03.05 Pedagogical education (with two training profiles), profile: Informatics - Physics.

During the forming stage of the experiment, the students of the experimental group mastered the specialized original distance-learning course "Pedagogical interaction with gifted children in modern education", which covers topical issues of the phenomenon of children's giftedness, the problems of identifying and developing children's giftedness, and the implementation of pedagogical support for gifted students. The students of the experimental group took an active part in practical exercises, online conferences, passed the final testing procedure, successfully applied their new knowledge about the phenomenon of children's giftedness.

The control group consisted of the 2nd-year undergraduate students, specialty: 44.03 .05 Pedagogical education (with two training profiles), profile: Mathematics - Continuing Education.

The implementation of the planned pedagogical conditions in the experimental group of students made it possible to carry out repeated pedagogical diagnostics with the use of the methods applied at the ascertaining stage of the research. We used the obtained data to compare the indicators of the initial and formed readiness of future teachers to work with gifted children, illustrated them in a diagram (Fig. 3), and reflected the degree of change in the propensity of students to work with gifted children (Fig. 4).

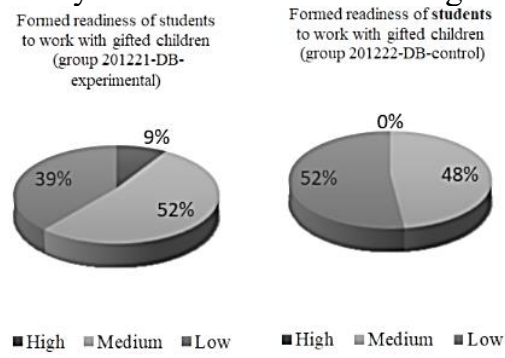

Fig. 3. The formed readiness of future teachers to work with gifted children (\%)

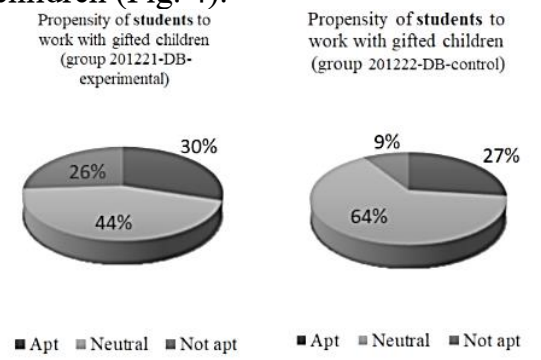

Fig. 4. Changes in the propensity of future teachers to work with gifted children (\%) 
The results of the repeated diagnostics were summarized, analyzed, and compared. The evidence base indicates the effectiveness of the chosen form, means, and methods of forming the readiness of future teachers to work with gifted children.

Repeated questionnaire survey and testing of the experimental group at the control stage showed an increase in the level of readiness and propensity of the majority of students to work with gifted children. $9 \%$ of subjects of the experimental group showed to have potential internal abilities to work with gifted children. There is also a high ability to stimulate independent creative activity. $52 \%$ of the group showed a tendency to interact with gifted children but also a need for additional motivational and stimulating efforts for their active self-regulation of the intellectual process. A propensity to work with gifted children was found to the least degree in 39\%. The students of this group do not have a personal desire for this type of activity. However, with the appropriate mobilization of internal forces, selfconfidence, and hard work, future teachers can achieve certain results in their work with gifted children.

The control group of students had no significant changes in the formation of readiness and an increase in propensity to work with gifted children. Thus, the results of the control stage of our experimental work confirmed the completion of the assigned tasks.

Based on the analysis of the results of the experimental work we can state that the implementation of specially created conditions for the formation of the future teacher's readiness to work with gifted children made it possible to better form the future teacher's readiness to work with gifted children in the experimental group of students. In the experimental group, the segment of students characterized by high and medium readiness to work with gifted children increased by $9 \%$, which is $8 \%$ higher than the results of the control group, which showed slight positive changes in their readiness to work with gifted children upon completion of the experimental work $(1 \%)$.

The results of our pedagogical experiment reflect the fact that the students of the experimental group have achieved positive changes in their professional readiness to work with gifted children. Also, the entire course of experimental work confirms the need and effectiveness of the formation of the future teacher's readiness to work with gifted children within the higher education system by way of specially created pedagogical conditions.

\section{References}

1. D. Rupalestari, S. Prabawanto, Journal of Physics: Conference Series, 1521(3), 032054 (2020)

2. J. Gralewski, Thinking Skills and Creativity, 31, 138 (2019)

3. A.M. Matiushkin, Secrets of giftedness, 128 (1993)

4. A.I. Savenkov, Psychology of children's giftedness, 440 (2010)

5. V.S. Iurkevich, S.S. Iurkevich, Modern foreign psychology, 2(2), 87 (2020)

6. D.B. Bogoiavlenskaia, Intellectual activity as a problem of creativity, 173 (1983)

7. L.I. Larionova, Cultural and psychological factors in the development of intellectual giftedness, 320 (2011)

8. L.I. Larionova, “Izvestiya IPPO” Scientific journal of SAEI HE MSPU, 4, 75 (2017) 